\title{
Effects of climate and eutrophication on the diversity of hard bottom communities on the Skagerrak coast 1990-2010
}

\author{
K. M. Norderhaug ${ }^{1,2, *}$, H. Gundersen ${ }^{1,2}{ }^{\text {, A. Pedersen }}{ }^{1}$, F. Moy ${ }^{3}$, N. Green ${ }^{1}$, \\ M. G. Walday ${ }^{1}$, J. K. Gitmark ${ }^{1}$, A. B. Ledang ${ }^{1}$, B. Bjerkeng ${ }^{1}$, D. Ø. Hjermann ${ }^{1,2}$, \\ H. C. Trannum ${ }^{1}$

\begin{abstract}
${ }^{1}$ Norwegian Institute for Water Research (NIVA), Gaustadalléen 21, 0349 Oslo, Norway
${ }^{2}$ Department of Biosciences, University of Oslo, PO Box 1066, Blindern, 0316 Oslo, Norway

${ }^{3}$ Institute of Marine Research, Flødevigen Research Station, Nye Flødevigveien 20, 4817 His, Norway
\end{abstract}

\begin{abstract}
Eutrophication is one of the most serious environmental problems in the Skagerrak, and climate change may increase eutrophication in the future. This study focused on the effects of eutrophication and climate, and the interactions between these 2 factors, on biodiversity in rocky bottom communities on the outer Skagerrak coast. Monitoring data from the period 1990 to 2010 including macroalgae, sessile fauna and physical and hydrochemical data were analysed. In total, $45 \%$ of the total variance in the communities could be explained by physical factors and factors related to climate and eutrophication. The most important factors regulating species richness, diversity and community structure were wave exposure level and other factors varying with depth and biogeographical region. The benthic ecosystems were overall dominated by perennial and annual algae and rich communities of sessile macroinvertebrates. Climate variation and eutrophication variables had small but consistent impacts on the communities. Periods with high particle concentrations and with extreme temperatures negatively impacted benthic diversity. The responses to nutrients were variable and dependant on season and species. In January, when measurements best reflect available nutrients in the system, the species richness and diversity responses were concave, with the greatest richness and diversity in periods with intermediate nutrient concentrations. This pattern may indicate that our communities were in an elevated eutrophication state in periods with high nutrient concentrations and in the enrichment phase in periods with low concentrations. The study highlights the importance of regarding multiple stressors in combination and indicates that climate change may decrease benthic diversity in the Skagerrak in the future.
\end{abstract}

KEY WORDS: Hard bottom communities $\cdot$ Diversity $\cdot$ Climate change $\cdot$ Eutrophication

\section{INTRODUCTION}

Environmental management needs a better understanding of coastal ecosystem dynamics in order to understand effects of multiple stressors, including eutrophication (anthropogenic enrichment of nutrients; OSPAR 1998) and climate change, and how they interact (Frid et al. 2005, Rabalais et al. 2009).

${ }^{*}$ Corresponding author: kjell.norderhaug@niva.no
Changes in water quality and transparency (Mankovsky et al. 1996, Sanden \& Håkansson 1996, Aksnes \& Ohman 2009, Aksnes et al. 2009) and large-scale ecosystem shifts (e.g. Steneck et al. 2004) in the coastal zone are occurring globally. Eutrophication is also one of the most serious and challenging environmental problems in the North Sea (OSPAR 2010) and Skagerrak (Boesch et al. 2006, Diaz \& Rosenberg

(C) The authors 2015. Open Access under Creative Commons by Attribution Licence. Use, distribution and reproduction are unrestricted. Authors and original publication must be credited. 
2008). The coastal zone is under pressure from eutrophication locally and regionally. Nutrients are carried to the Skagerrak from land via rivers from agriculture, forestry and sewage plants as well as by ocean currents and atmospheric depositions. While recent studies suggest that eutrophication and climate change have only caused small changes in benthic (soft bottom) communities in the central North Sea (Frid et al. 2009, Kröncke et al. 2011), large-scale regime shifts in the pelagic (Frigstad et al. 2013) and in the rocky benthos on the inner coast (Moy \& Christie 2012) as well as declines in coastal fish stocks (Kålås et al. 2006) have been reported.

Climate change may add to already elevated eutrophication and hence calls for strong management actions in order to prevent severe effects in coastal waters. The North Sea water temperature has increased by 1 to $2^{\circ} \mathrm{C}$ since 1985 (OSPAR 2010), and many species have extended their distribution further north (e.g. Lindley \& Batten 2002). Increasing temperature is expected to increase the global rate of species extinction (Thomas et al. 2004), and warming is expected to reduce the resilience of macrophyte ecosystems in the Skagerrak (Moy \& Christie 2012). The awareness of indirect effects on coastal water chemistry resulting from climate change in oceanography and run-off from land has increased (Harley et al. 2006, Aksnes \& Ohman 2009). By increasing and extending periods with run-off from land (caused by increased precipitation and shorter freezing periods during winter), climate change is expected to increase eutrophication in the coastal zone (Rabalais et al. 2009). Frigstad et al. (2013) showed that a regime shift in the water chemistry occurred on the Norwegian Skagerrak coast with increased concentrations of particles and nutrients after 2000 compared to before 2000 .

While a number of studies have addressed the impact from eutrophication in deeper soft bottom communities in the North Sea (e.g. Frid et al. 2009, Kröncke et al. 2011), the effects on hard bottom communities in shallow water are less well known. Hard bottom communities in the littoral and shallow sublittoral zone are generally strongly structured vertically by physical and biological factors (e.g. Connell 1961), and on the Norwegian coast, they are subject to stochastic and strong disturbances such as changing wave conditions, freshwater inputs from runoff, ice, sediments, and nutrients (Syvertsen et al. 2009). While unpredictable changes in the physical and chemical environment are expected to result in large natural variation in the community structure, waves and high water exchange result in a short retention time. Consequently, shallow water species may have evolved higher tolerance to changing conditions, and hard bottom communities may be more resistant to eutrophication compared to soft bottom communities. Eutrophication effects on hard bottom communities include increased primary production, changes in species composition and biomass, shading, and increased sedimentation on the benthos (Gray 1992, Nilsson \& Rosenberg 2000, Kraufvelin et al. 2006).

We used data from the Coastal Monitoring Programme (KYO; Norderhaug et al. 2011a), which was established as a response to the Prymnesium polylepis (Edvardsen et al. 2011; Syn. Chrysochromulina polylepis Manton \& Parke 1962) toxic bloom in 1988 that had severe effects on ecosystems throughout the Skagerrak and resulted in mass mortality in various organism communities and fish farms (Olsgard 1993, Gjøsæter et al. 2000). The bloom was caused by elevated anthropogenic nutrient inputs to the Skagerrak from the Baltic and south North Sea (Dahl \& Johannessen 1998). Skagerrak receives large regional nutrient inputs from European rivers via the northflowing Jutland Coastal Current (Aure \& Magnusson 2008). Local inputs to the Skagerrak coastal water are dominated by the Glomma River in the outer Oslofjord, in the eastern part of the monitoring area.

The aim of this study was to analyse how variation in the eutrophication level and climate affect coastal benthic communities on rocky bottoms on the Skagerrak coast within the period 1990 to 2010. Specifically, we wanted to identify the most important physical and chemical factors structuring the hard bottom communities and reveal how different levels of salinity, temperature, nutrients, and suspended particles have impacted the community diversity and structure. Important aims were also to identify interactions between climate and eutrophication and explore how diversity responded to nutrients as an indication of the eutrophic state of the communities (sensu Pearson \& Rosenberg 1978).

\section{MATERIALS AND METHODS}

\section{Sampling design}

The Coastal Monitoring Programme (KYO) was run from 1990 to 2010, and thus $21 \mathrm{yr}$ of KYO data were available (see also Norderhaug et al. 2011b). The station network remained largely the same throughout the monitoring period (Fig. 1), but with some changes for financial and logistical reasons. The biological stations were located at sloping rocky bottom from 0 to 


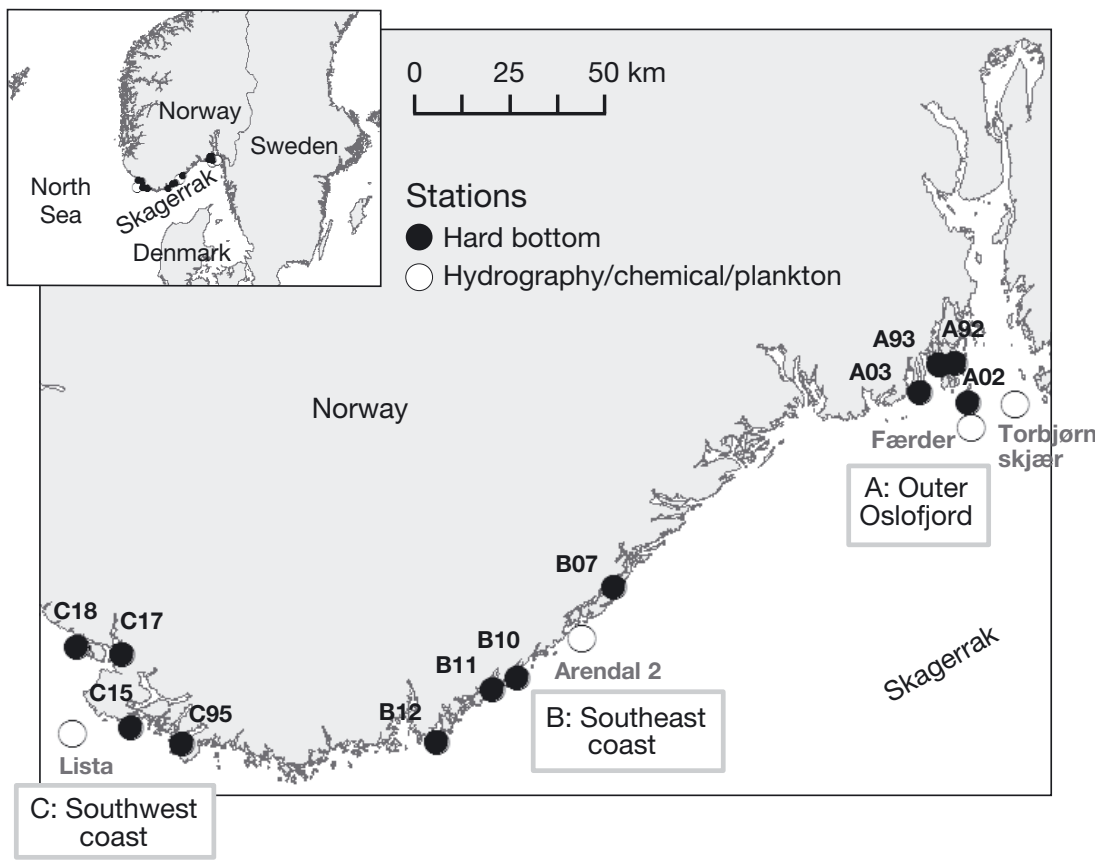

Fig. 1. Stations monitored within the Norwegian Coastal Monitoring Programme through 1990 to 2010 (Pedersen \& Rygg 1990, Norderhaug et al. $2011 \mathrm{~b}$ ) and used for the present study. The stations were positioned in 3 areas from east to west: the outer Oslofjord, the southeast coast and the southwest coast, and 4 biological stations were established in each area. These stations were situated close to fixed hydrographical stations where CTD profiling and water sampling for hydrochemical analyses were performed west coast were only monitored from 2002 to 2010 (Table 1). One hydrographical station was assumed to represent the hydrochemical conditions for the 4 biological stations within each area. The water at the hydrochemical stations represents the water at the biological stations well (NIVA 2002). Due to logistical and financial reasons, the position of the hydrochemical station in the outer Oslofjord has been adjusted within the same water mass 3 times during the monitoring period: Færder at $10.55^{\circ} \mathrm{E}, 58.97^{\circ} \mathrm{N}$ (19901992 and 2002-2007), Torbjørnskjær at $10.77^{\circ} \mathrm{E}, \quad 59.03^{\circ} \mathrm{N} \quad(1995-1998$ and $2001)$, and $\mathrm{OF}-1$ at $10.75^{\circ} \mathrm{E}, 59.03^{\circ} \mathrm{N}$ (2008-2010). It was assumed that these adjustments have not influenced the results significantly.

\section{Biological data}

The 12 fixed stations for biological data were visited once per year during June. Semi-quantitative registra-

$30 \mathrm{~m}$ depth (or maximum hard bottom depth), as far as possible from the coastline and disturbance from local eutrophication sources. The biological stations A92 and A93 in the outer Oslofjord and C95 on the south- tion (0: absent, 1: single specimen, 2: scattered, 3: common, and 4: dominating) of all algae and fauna species (or taxa) was performed along transects by 2 scientific divers (1 expert in algal and faunal taxon-

Table 1. The total dataset of biological stations matched with hydrochemical data from representative stations in outer Oslofjord, southeast coast and southwest coast. Values in each cell indicate the number of depth levels covered for biological data (before slash) and hydrochemical data (after slash) for each combination of year and station. Hydrographical data are missing from 10 m depth level for Stns A02 and A03 in 2001

\begin{tabular}{|c|c|c|c|c|c|c|c|c|c|c|c|c|c|c|c|c|c|c|c|c|c|}
\hline Station & 90 & 91 & 92 & 93 & 94 & 95 & 96 & 97 & 98 & 99 & 00 & 01 & 02 & 03 & 04 & 05 & 06 & 07 & 08 & 09 & 10 \\
\hline \multicolumn{22}{|c|}{ Oslofjord } \\
\hline A02 & $3 / 3$ & $0 / 3$ & $0 / 3$ & $0 / 0$ & $3 / 0$ & $3 / 3$ & $3 / 3$ & $3 / 3$ & $3 / 3$ & $0 / 0$ & $3 / 0$ & $3 / 2$ & $3 / 3$ & $3 / 3$ & $3 / 3$ & $3 / 3$ & $3 / 3$ & $3 / 3$ & $3 / 3$ & $3 / 3$ & $3 / 3$ \\
\hline A03 & $3 / 3$ & $3 / 3$ & $3 / 3$ & $3 / 0$ & $3 / 0$ & $3 / 3$ & $3 / 3$ & $3 / 3$ & $3 / 3$ & $3 / 0$ & $3 / 0$ & $3 / 2$ & $3 / 3$ & $3 / 3$ & $3 / 3$ & $3 / 3$ & $3 / 3$ & $3 / 3$ & $3 / 3$ & $3 / 3$ & $3 / 3$ \\
\hline A92 & $0 / 3$ & $0 / 3$ & $0 / 3$ & $0 / 0$ & $0 / 0$ & $0 / 3$ & $0 / 3$ & $0 / 3$ & $0 / 3$ & $0 / 0$ & $0 / 0$ & $0 / 2$ & $3 / 3$ & $3 / 3$ & $3 / 3$ & $3 / 3$ & $3 / 3$ & $3 / 3$ & $3 / 3$ & $3 / 3$ & $3 / 3$ \\
\hline A93 & $0 / 3$ & $0 / 3$ & $0 / 3$ & $0 / 0$ & $0 / 0$ & $0 / 3$ & $0 / 3$ & $0 / 3$ & $0 / 3$ & $0 / 0$ & $0 / 0$ & $0 / 2$ & $3 / 3$ & $3 / 3$ & $3 / 3$ & $3 / 3$ & $3 / 3$ & $3 / 3$ & $3 / 3$ & $3 / 3$ & $3 / 3$ \\
\hline \multicolumn{22}{|l|}{ SE coast } \\
\hline B07 & $3 / 3$ & $3 / 3$ & $3 / 3$ & $3 / 3$ & $3 / 3$ & $3 / 3$ & $3 / 3$ & $3 / 3$ & $3 / 3$ & $3 / 3$ & $3 / 3$ & $3 / 3$ & $3 / 3$ & $3 / 3$ & $3 / 3$ & $3 / 3$ & $3 / 3$ & $3 / 3$ & $3 / 3$ & $3 / 3$ & $3 / 3$ \\
\hline B10 & $3 / 3$ & $3 / 3$ & $3 / 3$ & $3 / 3$ & $3 / 3$ & $3 / 3$ & $3 / 3$ & $3 / 3$ & $3 / 3$ & $3 / 3$ & $3 / 3$ & $3 / 3$ & $3 / 3$ & $3 / 3$ & $3 / 3$ & $3 / 3$ & $3 / 3$ & $3 / 3$ & $3 / 3$ & $3 / 3$ & $3 / 3$ \\
\hline B11 & $3 / 3$ & $3 / 3$ & $3 / 3$ & $3 / 3$ & $3 / 3$ & $3 / 3$ & $3 / 3$ & $3 / 3$ & $3 / 3$ & $3 / 3$ & $3 / 3$ & $3 / 3$ & $3 / 3$ & $3 / 3$ & $3 / 3$ & $3 / 3$ & $3 / 3$ & $3 / 3$ & $3 / 3$ & $3 / 3$ & $3 / 3$ \\
\hline B12 & $3 / 3$ & $3 / 3$ & $0 / 3$ & $0 / 3$ & $0 / 3$ & $3 / 3$ & $3 / 3$ & $3 / 3$ & $3 / 3$ & $3 / 3$ & $3 / 3$ & $3 / 3$ & $3 / 3$ & $3 / 3$ & $3 / 3$ & $3 / 3$ & $3 / 3$ & $3 / 3$ & $3 / 3$ & $3 / 3$ & $3 / 3$ \\
\hline \multicolumn{22}{|c|}{ SW coast } \\
\hline C15 & $3 / 0$ & $3 / 3$ & $3 / 3$ & $3 / 3$ & $3 / 3$ & $3 / 3$ & $3 / 3$ & $3 / 3$ & $3 / 3$ & $3 / 3$ & $3 / 3$ & $3 / 3$ & $3 / 3$ & $3 / 3$ & $3 / 3$ & $3 / 3$ & $3 / 3$ & $3 / 3$ & $3 / 3$ & $3 / 3$ & $3 / 3$ \\
\hline C17 & $3 / 0$ & $3 / 3$ & $3 / 3$ & $3 / 3$ & $3 / 3$ & $3 / 3$ & $3 / 3$ & $3 / 3$ & $3 / 3$ & $3 / 3$ & $3 / 3$ & $3 / 3$ & $3 / 3$ & $3 / 3$ & $3 / 3$ & $3 / 3$ & $3 / 3$ & $3 / 3$ & $3 / 3$ & $3 / 3$ & $3 / 3$ \\
\hline C18 & $3 / 0$ & $3 / 3$ & $3 / 3$ & $3 / 3$ & $3 / 3$ & $3 / 3$ & $3 / 3$ & $3 / 3$ & $3 / 3$ & $3 / 3$ & $3 / 3$ & $3 / 3$ & $3 / 3$ & $3 / 3$ & $3 / 3$ & $3 / 3$ & $3 / 3$ & $3 / 3$ & $3 / 3$ & $3 / 3$ & $3 / 3$ \\
\hline C95 & $0 / 0$ & $0 / 3$ & $0 / 3$ & $0 / 3$ & $0 / 3$ & $0 / 3$ & $0 / 3$ & $0 / 3$ & $0 / 3$ & $0 / 3$ & $0 / 3$ & $0 / 3$ & $3 / 3$ & $3 / 3$ & $3 / 3$ & $3 / 3$ & $3 / 3$ & $3 / 3$ & $3 / 3$ & $3 / 3$ & $3 / 3$ \\
\hline
\end{tabular}


omy respectively on each visit) or brought back to the laboratory for later identification if the species could not be recognized in situ. Registrations of all species visible (approximately $0.5 \mathrm{~m}$ each way from the diver position, i.e. $1 \mathrm{~m}^{2}$ at each depth) were made for every meter from $1 \mathrm{~m}$ above to $4 \mathrm{~m}$ below surface and for every second meter from 4 to maximum $30 \mathrm{~m}$ (or deepest possible) below the surface. Data were available to maximum $24 \mathrm{~m}$ depth from all stations, and this depth was consequently used as maximum depth for all stations in the analysis. More than 1100 species (taxa) were recorded and were subject to this study. Multivariate analysis revealed that the communities were separated into 3 distinct depth zones (0-3, 4-15, and 16-24 m; see Fig. 5a). Because of this and because hydrochemical data are only available from some depths, the Shannon-Wiener diversity index ( $H^{\prime}$; Shannon \& Weaver 1963) and species richness $(S)$ were calculated at each station for each of the 3 depth zones for use in univariate analysis and the sum of the semi-quantitative occurrence of each species was pooled across each depth zone for use in multivariate analysis. A complete dataset from 12 biological stations, 3 depth zones, and 21 yr would have 756 observations, but due to changes in the station network, and bad weather conditions, there are some missing data in observation frequency, depth coverage, and certain parameters at some stations, resulting in a total of 624 biological observations (Table 1).

\section{Hydrochemical data}

Hydrochemical and oceanographic data were gathered monthly or twice a month from the 4 fixed water column (0 $\mathrm{m}$ sea floor) sampling stations with the use of CTD (temperature and salinity) and water samples. Sampling was performed according to OSPAR Guidelines for the Joint Assessment and Monitoring Programme (JAMP; OSPAR 2009), ICES technical manuals, and NS-ISO 5667-9:1992. Samples were taken at $0,5,10,20,30,50,100,125,150$, and $200 \mathrm{~m}$, but only samples from 0,10 , and $20 \mathrm{~m}$ were used for the analyses to match the depths of the biological data. We chose data from July and October (the year before) and January and April (for the same year) to represent the conditions for the 4 seasons preceding the biological sampling. A complete dataset with seasonal (4) records from $21 \mathrm{yr}$ at the 3 stations and 3 depth zones used would have resulted in 756 values per variable, but as with the biological data, there were some missing observations due to miscellaneous failures, resulting in a total of 700 hydrochemical values per variable (Table 1). The full dataset consisted of 607 records with both biological and hydrochemical data (Table 1).

We derived season-specific variables for analyses based on the levels of salinity, temperature, total phosphorus (TotP), $\mathrm{PO}_{4}^{3-}$ (phosphate), total nitrogen (TotN), $\mathrm{NO}_{3}{ }^{-}+\mathrm{NO}_{2}{ }^{-}$(nitrate + nitrite), $\mathrm{NH}_{4}{ }^{+}$(ammonium), $\mathrm{SiO}_{3}{ }^{2-}$ (silicate), phytoplankton biomass measured as chlorophyll a ( $\mathrm{chl}$ a), particulate organic carbon, nitrogen, and phosphorus (POC, PON, and POP), total suspended matter (TSM), Secchi depth, and oxygen $\left(\mathrm{O}_{2}\right)$. For chl a, salinity, and temperature, we also selected the maximum and minimum values observed during the last 12 mo before the time of biological sampling in June (the life-time of most species). Also, Hurrell North Atlantic Oscillation (NAO; Bjerknes 1964) during winter (December through February) was included as a climate predictor, describing the general climate during winter before the biological sampling was performed. Wave exposure level (SWM) has been modelled for the whole study area (according to Isæus 2004) and was extracted from a GIS layer with spatial resolution at $25 \times 25 \mathrm{~m}$ and included as a predictor in the modelling. To account for potential biogeographical variation across the monitoring area, longitude was included as a predictor variable in the models as well as depth, which was used as a proxy for possible depth-related factors such as light intensity.

The high number of environmental variables available, the fact that some of the series were incomplete, and the fact that many of the variables were correlated (see Supplement 2 at www.int-res.com/articles/ suppl/m530p029_supp.pdf) made it necessary to perform some a priori variable selection before the actual analyses of eutrophication and climate effects on coastal benthic communities could be performed (see 'Statistical methods').

\section{Statistical methods}

A first screening of the predictors revealed that some of the variables were incomplete, and these variables were therefore removed due to missing data. These variables were ammonium and total suspended matter for all 4 seasons and Secchi depth. Furthermore, several of the variables were highly correlated and needed to be removed before modelling took place. Thus, to decide which variables should be selected for the analyses and which to exclude in an objective manner, we chose a procedure in which we 
included groups of related predictors in 3 different principal component analyses (PCA; ter Braak \& Smilauer 2002) to visually inspect which variables 'pulled in the same direction' (i.e. correlated) and therefore which of a group of predictors showed the highest contribution to the first 2 principal components (i.e. the longest arrows in the PCA plot) and thus was the best representative for that group.

Both uni- and multivariate numerical and statistical methods were used to analyse how variations in the eutrophication level and climate affect coastal benthic communities on rocky bottoms. Boxplots were made to check for visual temporal trends in the overall pattern of diversity $\left(H^{\prime}\right)$, species richness $(S)$, and the whole range of eutrophication and climate predictors. To check for temporal trends in the amount of macroalgae and -invertebrates, linear regressions were performed for each station and organism group separately.

Generalized additive mixed models (Mixed GAM; Zuur et al. 2009) were used to test for possible effects of climate and eutrophication on diversity $\left(H^{\prime}\right)$ and species richness $(S)$. The R package $m g c v$ (Wood 2011) was used for this purpose. The smoothing parameter $k$ was chosen to be at maximum 3 for all continuous predictors, to allow for a limited degree of non-linear effects, if present. Station number was included as a random factor to account for nonindependence among observations taken at the same site. For both responses, a high number of models were tested, using all possible combinations of predictor variables as candidate models by the use of the R package MuMIn (Barton 2013). The Akaike information criterion ( $\mathrm{AICc}_{\text {; }}$ Burnham et al. 2011), corrected for sample size, was used to select the most parsimonious model of the ones tested. Ultimately, the number of candidate models should be small to avoid generating so many models that spurious findings become likely (Burnham \& Anderson 2002), but in our case, choosing only a selection of models would be somewhat arbitrary due to a very high number of likely models. However, the potential for spurious findings was reduced by presenting importance tables based on all models that were regarded as approximately equally good, i.e. having $\triangle \mathrm{AICC}$ values $<7$ (Burnham et al. 2011). The candidate mixed GAMs for each of the responses took approximately $1 \mathrm{wk}$ to run on the computer, and including interactions in these models would have increased the computational time further in an exponential way for each interaction included. Still, we wished to test for the potential non-additive effects of eutrophication and climate, so we performed another round of analyses in which we included the interactions between eutrophication and climate to the best candidate models that included the 2 component variables of the interaction, with each interaction in separate models. All basic analyses and mixed GAMs were performed in R (v. 2.15.1; R Development Core Team 2012).

The response curves of diversity and species richness to the hydrochemical variables are shown in Supplement 1 at www.int-res.com/articles/suppl/ m530p029_supp.pdf. The most important variables are shown as partial response curves of each interaction that were included in the best of the mixed GAM models which included the 2 component variables of the interaction. The 4 variables with lowest importance for species richness and diversity, minimum salinity $\left(\mathrm{S}_{\mathrm{min}}\right)$, particle concentration during July the previous year $\left(\mathrm{POC}_{\mathrm{Jul}}\right)$, longitude, and phosphate concentrations during January, were not included in any of the interactions of the final models and are thus not shown graphically.

For multivariate analysis, distance-based multivariate analysis for a linear model (DISTLM; Anderson 2001) in the PRIMER package v. 6.1.13 (Clarke \& Warwick 2001) was used for identification of ecosystem changes (structure and composition) and for identification of the most important variables responsible for these changes. A stepwise selection procedure based on the Akaike selection criterion AICc was used for selecting the best explanatory model. Distance-based redundancy analysis (dbRDA) plots with vector overlays were used for displaying relationships between community patterns and variables in the dataset. A clear depth zonation in the distribution of species was identified (see Fig. 5a). In the multivariate analyses, community data were therefore averaged within each depth zone $(0-3,4-15$, and 16-24 $\mathrm{m}$ depth), and variable data sampled from 0 , 10 , and $20 \mathrm{~m}$ were used for each zone. Two-way SIMPER (Clarke \& Warwick 2001) was used for identifying the most important species accounting for community responses to each of the variables identified by DISTLM. The variables were grouped according to level, 'low', 'medium', and 'high'. The species were identified by comparing the 'low' and 'high' groups. To reduce the risk of obtaining spurious results from not being able to take into account $>2$ variables in each analysis, SIMPERs for each variable were run with station number, wave exposure level, and depth zone, respectively, as the second variable in separate runs. The species that were most important in explaining the observed variation across all runs were listed in the results. 

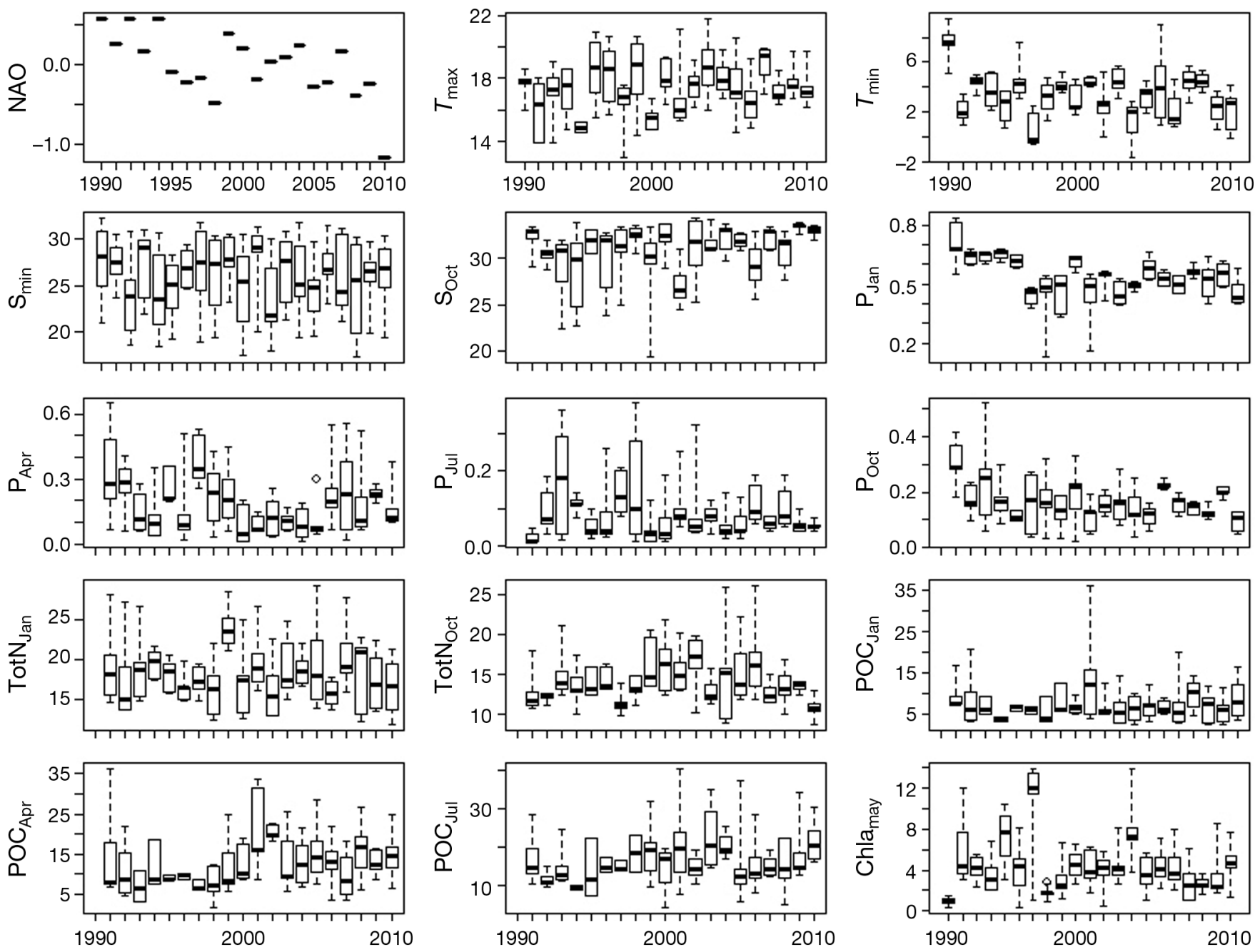

Fig. 2. Variation of hydrochemical variables from 1991 to 2010 used as predictors in the statistical analyses. Data are pooled for stations and depths. Variables: North Atlantic Oscillation index (NAO); maximum temperature $\left(T_{\max }\right)$; minimum temperature $\left(T_{\min }\right)$; salinity in October $\left(\mathrm{S}_{\text {Oct }}\right)$; phosphate concentration in April $\left(\mathrm{P}_{\mathrm{Apr}}\right)$, July $\left(\mathrm{P}_{\mathrm{Jul}}\right)$, and October $\left(\mathrm{P}_{\text {Oct }}\right)$; total nitrogen in January $\left(\right.$ TotN $\left._{\text {Jan }}\right)$ and October $\left(\right.$ TotN $\left._{\mathrm{Oct}}\right)$; particulate organic carbon in January $\left(\mathrm{POC}_{\mathrm{Jan}}\right)$, April $\left(\mathrm{POC}_{\mathrm{Apr}}\right)$ and July $\left(\mathrm{POC}_{\mathrm{Jul}}\right)$; and maximum chlorophyll a $\left(\mathrm{Chla}_{\max }\right)$. Temperature $(T)$ is given in ${ }^{\circ} \mathrm{C}$, salinity $(\mathrm{S})$ in ppt, and nutrients, i.e. phosphate $\left(\mathrm{PO}_{4}{ }^{3-}\right)$ and total nitrogen (TotN), and particles (particulate organic carbon [POC]), in $\mu \mathrm{M}$. Boxes show median, interquartile range (IQR) and whiskers extending to the extreme values but still within 1.5 IQR of the lower and upper quartile, respectively

\section{RESULTS}

\section{Temporal variation in hydrochemistry}

The winter NAO in the Skagerrak was positive during the first few years of the monitoring period, characterized by mild winters and higher than average precipitation (Fig. 2). In 1998 and 2010, the winter NAO index was at its 2 most highly negative values, and characterized by cold and dry climate. The average water temperature was between 0 and $8{ }^{\circ} \mathrm{C}$ in January to April. The maximum water temperature was usually recorded in July or August and ranged from 13 to $>20^{\circ} \mathrm{C}$ (Fig. 2). Particularly high temperatures were recorded during the summers of 1997, 2002, and 2006. The minimum temperature, $T_{\min }$, was usually recorded in January or February and was between -1 and $+4^{\circ} \mathrm{C}$. During some years, $T_{\min }$ was below $0^{\circ} \mathrm{C}$ for long periods (e.g. 1996, 2003, and 2009). Minimum salinity varied between approximately 20 to $>30$ ppt.

Substantial variation in nutrient and particle concentrations was recorded through the monitoring period. Higher nutrient concentrations (phosphate) were measured during winter (January) than later in the year (April, July, and October). Particle concen- 

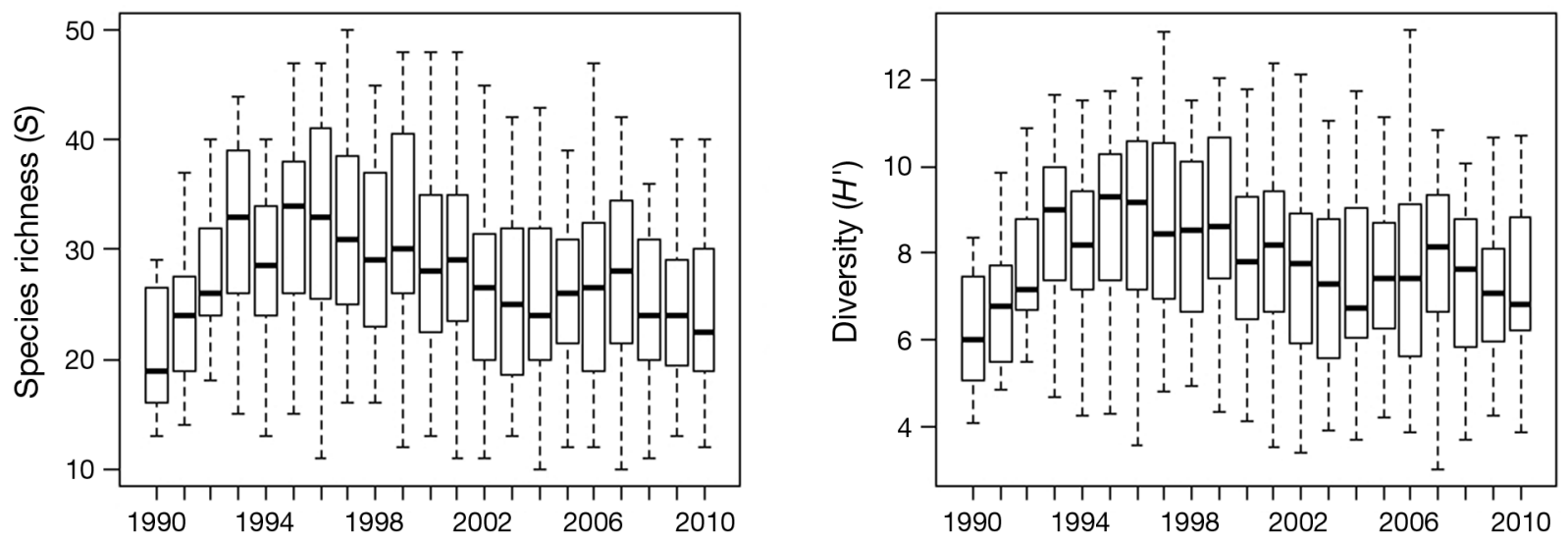

Fig. 3. The total richness $(S)$ and diversity (expressed as Shannon-Wiener diversity index $H^{\prime} ;$ Hill 1973 ) of all species from 1991 to 2010. Data are pooled across all stations and depths. See Fig. 2 for box definitions

trations (POC) were typically low in January and high in April and sometimes July. High concentrations of POC were recorded more frequently after 2000 compared with before 2000. The amount of phytoplankton (measured as chl a) was low in January and high in April, and also in July, in some years.

\section{Temporal variation in hard bottom diversity and species richness}

Substantial year-to-year variation was found for the total species richness $(S)$ and diversity $\left(H^{\prime}\right)$ across all stations, (Fig. 3), but the $S$ and $H^{\prime}$ values were frequently low during the first few years of the monitoring period and frequently high during the period 1995 to 2000. The lowest species richness (Fig. 4a) and diversity (Fig. 4b) values were found in the littoral and shallow sublittoral zone (0 to $3 \mathrm{~m}$ depth) and highest values were at intermediate depths (4 to $15 \mathrm{~m})$, but occasionally the $S$ and $H^{\prime}$ at Stns B12 and C18 from the deepest zone (16 to $24 \mathrm{~m}$ ) were at least as high as at the intermediate depth zone.

\section{Responses of diversity and species richness to hydrochemical variables}

The first PCA analysis included all measures of POC, nitrogen and phosphorus and revealed high correlations within each month (all $r>0.56$ ); therefore, we chose POC to represent this group of variables since POC vectors were slightly longer than the others in the PCA plot (particulate organic nitrogen [PON] and particulate organic phosphorus [POP] also correlated with chl $a$ within their month with $\mathrm{r}$ up to 0.76 ).
POC for October was also removed due to its correlation with October salinities $(\mathrm{r}=0.58)$. The second PCA analysis included all phosphorus- and nitrogen-related nutrient variables and revealed that nitrate + nitrite, phosphate, and total phosphorus all represented much of the same variation. Thus, phosphate was chosen over nitrate + nitrite and total phosphorus since it defined the axes better for all seasons. Total nitrogen for January and October, but not so much for July and April, seemed to explain something unique in the PCA plot and are therefore also included as predictors in the analyses. The last PCA group included the climate-related predictors temperature, salinity, and winter NAO (December to February) in addition to $\mathrm{chl}$ a. Based on the PCA plot, we found it reasonable to exclude the 5 variables January and October salinities and January, April, and October temperatures and keep minimum temperature. Also, July $(\mathrm{n}=481)$ and maximum $(\mathrm{n}=597)$ temperature as well as April $(\mathrm{n}=477)$ and October $(\mathrm{n}=454) \mathrm{chl}$ a showed similar patterns in the PCA, and maximum temperature was selected before the others due to fewer missing values. Similarly, maximum chl a $(\mathrm{n}=574)$ was chosen over minimum $(\mathrm{n}=574)$, January $(\mathrm{n}=465)$ and July ( $\mathrm{n}=442) \mathrm{chl} a$, and minimum salinity $(\mathrm{n}=607)$ was chosen over April $(n=501)$ and July $(n=472)$ salinities. The remaining set of 18 uncorrelated environmental variables (depth and longitude included), and their importance in explaining species diversity and richness, then need to be interpreted as being representatives for other correlated variables. Therefore, we provide a correlation matrix which might be useful for considering potential confounding effects from the final set of predictor variables with the other environmental variables available (see Supplement 2 at www.int-res.com/articles/suppl/m530p029_supp.pdf). 
a
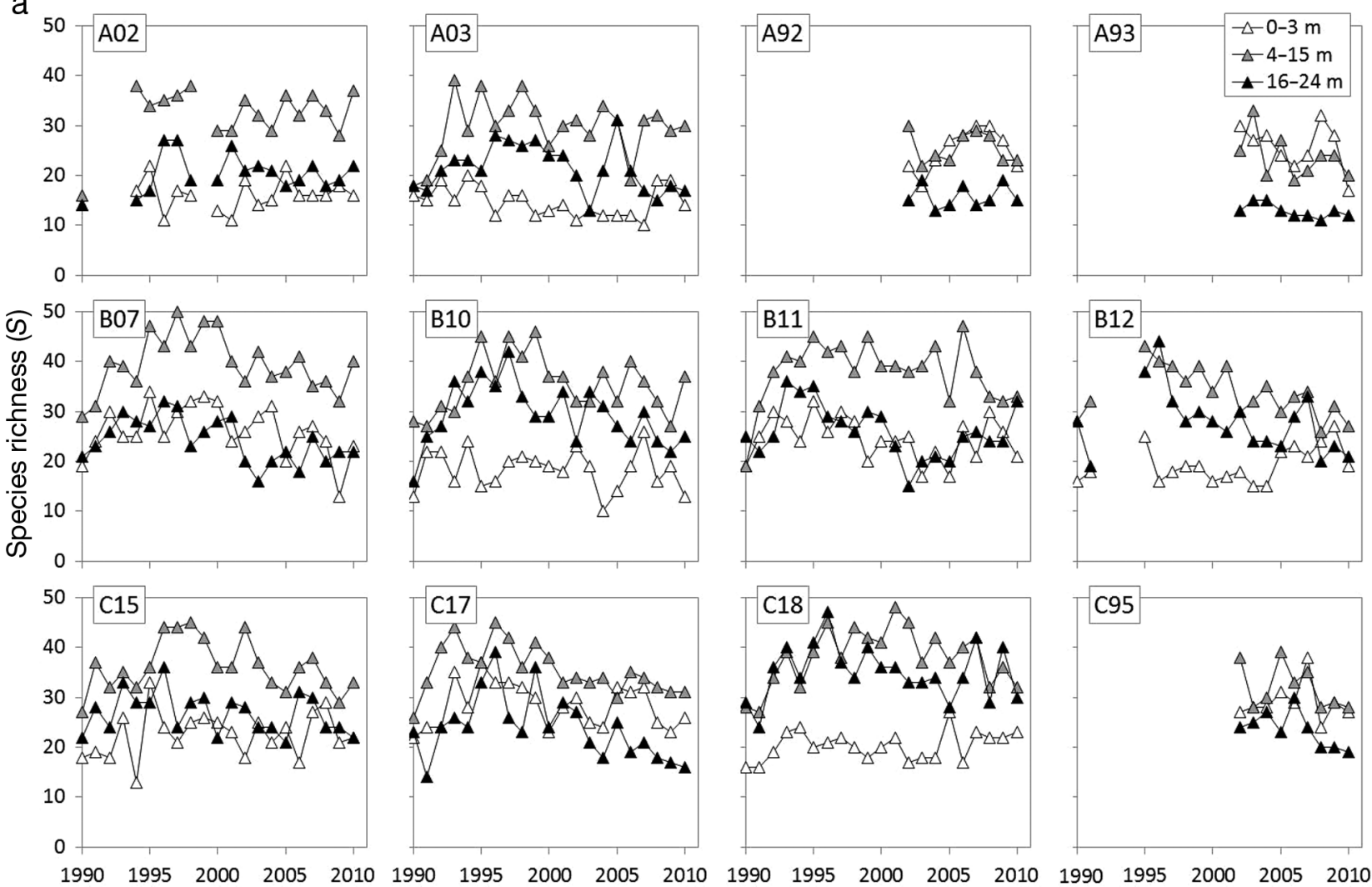

b
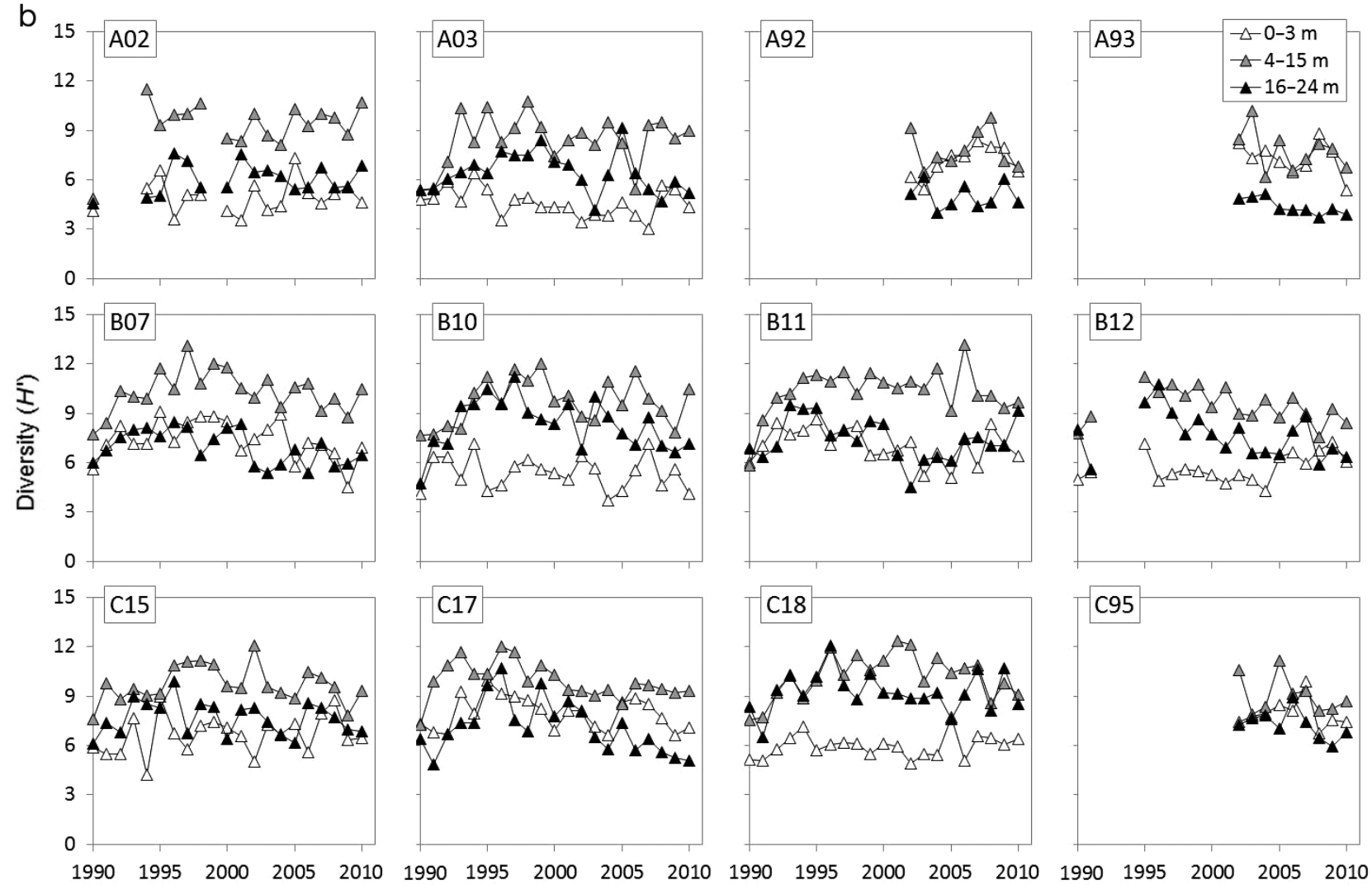

Fig. 4. (a) Species richness $(S)$ and (b) diversity (measured as Shannon-Wiener diversity index $H^{\prime}$ ) of all registered species of algae and fauna on hard bottom communities on the outer coast of Skagerrak for each station and 3 depth zones 
The relative importance of the predictors included in the mixed GAM models (i.e. the sum of Akaike weights over all models with $\triangle \mathrm{AICc}<7$; Barton 2013) is shown in Table 2. By setting the AICc limit as high as 7 (Burnham et al. 2011), we included the best models (33 models for $H^{\prime}$ and 181 for $S$ ) in the calculation of importance values. This was done to be able to range both the most and the least important variables against each other, i.e. avoiding too many variables of importance 0 or 1 . R-squared values for the selected models were all good, both for diversity $\left(\mathrm{R}^{2}\right.$ between 0.551 and 0.587$)$ and species richness $\left(\mathrm{R}^{2}\right.$ between 0.542 and 0.569 ). According to the mixed GAMs, the most important variables determining benthic species richness $(S)$ and diversity $\left(H^{\prime}\right)$ were depth, wave exposure level, nutrient concentrations $\left(\mathrm{PO}_{4}{ }^{3-}\right)$ the previous October, the maximum temperature the previous season (July or August; Table 2), and, in the case of species richness, geographical region (longitude). The maximum chl a concentration during spring bloom, the nutrient and particle concentration in winter (total nitrogen in January), the minimum temperature as well as the general winter climate (NAO) were also among the most important variables. Of less but significant importance were particle concentrations during spring $\left(\mathrm{POC}_{\mathrm{Apr}}\right)$ and phosphate concentrations winter to spring (phosphate concentrations in January and April). Particle concentrations the previous summer $\left(\mathrm{POC}_{\mathrm{Jul}}\right)$ and minimum salinity were of little importance.

High maximum temperatures ( $T_{\max }$ in Supplement 1 , typically in July or August) had a negative impact on the benthic species richness and diversity the following year. The species richness and diversity was particularly low after summers with temperatures exceeding approximately $18^{\circ} \mathrm{C}$. Interactions between $T_{\max }$ and phosphate concentrations in July and October also demonstrated that the decrease caused by high temperatures was smaller in combination with high nutrient concentrations during July and larger in combination with high nutrient concentrations during October. Low minimum temperatures $\left(T_{\min }\right.$, typically in January or February) had a smaller but significant negative effect on species richness and diversity. The general winter climate also affected diversity. High NAO (mild winters) promoted higher diversity than low NAO (dry and cold winters). Cold climate during winter in combination with high nutrient and particle concentrations in October to April decreased the diversity even more (the interactions between NAO and phosphate concentrations in October, total nitrogen in January, and POC in April, respectively).
Table 2. Analysis of diversity (Shannon-Wiener index $H^{\prime}$ ) and species richness $(S)$, ranked by importance for the responses. Importance is weighted over all candidate models with $\triangle \mathrm{AICC}<7$, and is 1 if the variable is included in all of these models, and 0 if it is included in none. Variables: Depth, modelled wave exposure level (SWM), maximum temperature $\left(T_{\max }\right)$, phosphate concentration in October $\left(\mathrm{P}_{\mathrm{Oct}}\right)$, maximum chlorophyll a (Chla $\mathrm{Cax}_{\text {ax }}$, North Atlantic Oscillation index (NAO), minimum temperature $\left(T_{\min }\right)$, particulate organic carbon in April $\left(\mathrm{POC}_{\mathrm{Apr}}\right)$, phosphate concentration in July $\left(\mathrm{P}_{\text {Jul }}\right)$, total nitrogen in January $\left(\operatorname{Tot}_{\mathrm{Jan}}\right)$, salinity in October $\left(\mathrm{S}_{\mathrm{Oct}}\right)$, phosphate concentration in April $\left(\mathrm{P}_{\mathrm{Apr}}\right)$, total nitrogen in October $\left(\mathrm{Tot}_{\mathrm{Oct}}\right)$, phosphate concentration in January $\left(\mathrm{P}_{\mathrm{Jan}}\right)$, longitude, particulate organic carbon in January $\left(\mathrm{POC}_{\mathrm{Jan}}\right)$, and minimum salinity $\left(\mathrm{S}_{\mathrm{min}}\right)$

\begin{tabular}{|c|c|c|c|}
\hline Variable & $\begin{array}{c}\text { Importance } \\
\text { (diversity) }\end{array}$ & Variable & $\begin{array}{c}\text { Importance } \\
\text { (species } \\
\text { richness) }\end{array}$ \\
\hline Depth & 1.00 & Depth & 1.00 \\
\hline SWM & 1.00 & $\mathrm{P}_{\text {Oct }}$ & 1.00 \\
\hline$T_{\max }$ & 1.00 & SWM & 1.00 \\
\hline $\mathrm{P}_{\mathrm{Oct}}$ & 0.80 & $T_{\max }$ & 1.00 \\
\hline Chla $_{\max }$ & 0.77 & Longitude & 1.00 \\
\hline $\mathrm{NAO}$ & 0.62 & Chla $_{\max }$ & 0.90 \\
\hline$T_{\min }$ & 0.28 & $\mathrm{NAO}$ & 0.89 \\
\hline $\mathrm{POC}_{\mathrm{Apr}}$ & 0.23 & $\mathrm{POC}_{\mathrm{Apr}}$ & 0.23 \\
\hline $\mathrm{P}_{\mathrm{Jul}}$ & 0.07 & $\operatorname{Tot}_{\mathrm{Jan}}$ & 0.23 \\
\hline TotN $_{\text {Jan }}$ & 0.05 & $\mathrm{P}_{\mathrm{Apr}}$ & 0.15 \\
\hline$S_{\text {Oct }}$ & 0.04 & $T_{\min }$ & 0.13 \\
\hline $\mathrm{P}_{\mathrm{Apr}}$ & 0.03 & $S_{\text {Oct }}$ & 0.13 \\
\hline TotN $\mathrm{N}_{\text {Oct }}$ & 0.02 & $\mathrm{P}_{\text {Jul }}$ & 0.08 \\
\hline $\mathrm{P}_{\text {Jan }}$ & 0.01 & TotN $\mathrm{N}_{\text {Oct }}$ & 0.03 \\
\hline Longitude & 0.01 & $\mathrm{P}_{\text {Jan }}$ & 0.02 \\
\hline $\mathrm{POC}_{\mathrm{Jul}}$ & 0.01 & $\mathrm{POC}_{\mathrm{Jul}}$ & 0.00 \\
\hline $\mathrm{S}_{\min }$ & 0.00 & $\mathrm{~S}_{\min }$ & 0.00 \\
\hline
\end{tabular}

The response of species richness and diversity to nutrients was concave in January when the phytoplankton production is negligible (see total nitrogen in January in Supplement 1). Lowest species richness and diversity was found in years with the highest total nitrogen concentrations in January (exceeding $25 \mu \mathrm{M})$. Highest species richness and diversity was found in years with intermediate concentrations (approximately $17 \mu \mathrm{M}$ ). The response was also negative to high nutrient concentrations the previous October (phosphate in October), particularly in years with low salinity during the same period (the interaction between phosphate and salinity in October). The responses of species richness and diversity to nutrients were variable but generally weakly positive in spring and summer (phosphate concentrations in April and July).

Species richness and diversity decreased with increasing particle concentrations early in the year $\left(\right.$ TotN $_{\text {Jan }}$ and $\left.\mathrm{POC}_{\mathrm{Apr}}\right)$. Lowest diversity was recorded 


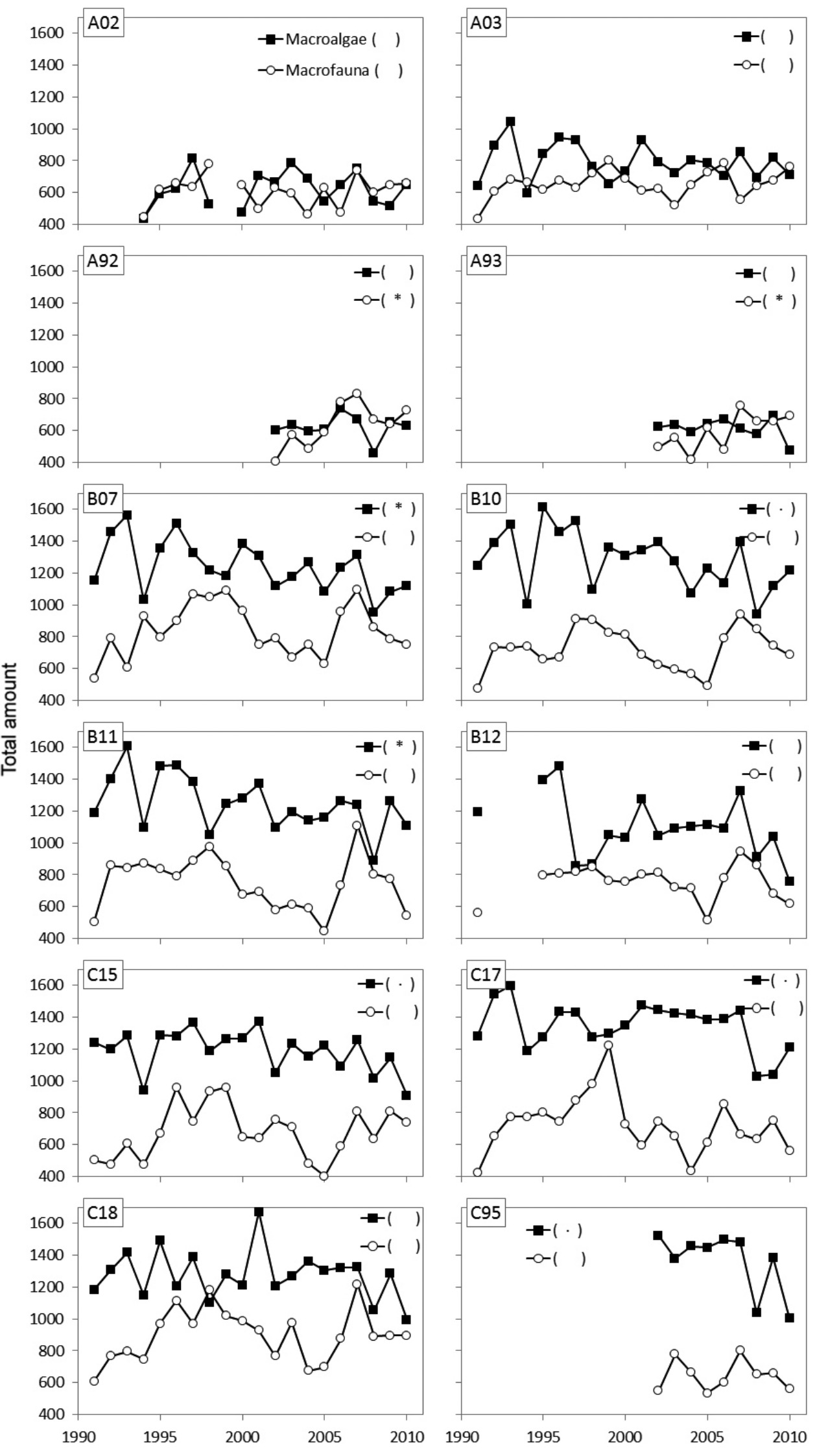

Fig. 5. The total number of registered species of macroalgae and -fauna summed over the 3 depth zones at each station for each year through the monitoring period. Symbols in parentheses indicate $\mathrm{p}$-values at $<0.05\left({ }^{*}\right)$, $<0.1(\cdot)$, and $>0.1$ ( ) for the regression through time for each combination of station and organism group 
with the combination of extreme temperatures and high concentrations of nutrients or particles, e.g. high phosphate concentrations the previous October in combination with high maximum temperature $\left(T_{\max }\right)$, or high POC in April in combination with low minimum temperature $\left(T_{\max }\right)$. The negative response to phytoplankton (chl a) was less pronounced (and concave) than to particulate organic carbon (POC), also shown by the interaction between POC concentrations in April and maximum chl $a$ in the case of species richness.

\section{Temporal variation in community structures}

Fig. 5 shows the total amount of macroalgae and sessile macroinvertebrates registered at each station and in different years. During the first few years in the monitoring period, the amounts of algae and invertebrates were increasing at most stations. However, there were few temporal trends in the total amount of registered algal and invertebrate species, and the abundances of these 2 major groups of organisms generally did not correlate (Fig. 5).

\section{Community responses to different hydrochemical variables}

According to the dbRDA plot in Fig. 6, $34 \%$ of the total variation in the data could be explained by the first 2 axes. Samples (shown in Fig. 6a) are distributed according to 3 depth zones along the $x$-axis (shown in Fig. 6b) with increasing depth from right to left. According to SIMPER, the littoral and shallow sublittoral zones were dominated by green, red, and brown macroalgae, littoral macroinvertebrates including barnacles (Balanus spp.), gastropods (in the genus Littorina and Patella), mussels (Mytilus edulis), and perennial brown algae including seaweeds (Fucus) and kelp (Laminaria spp., Saccharina latissima, and Alaria esculenta;
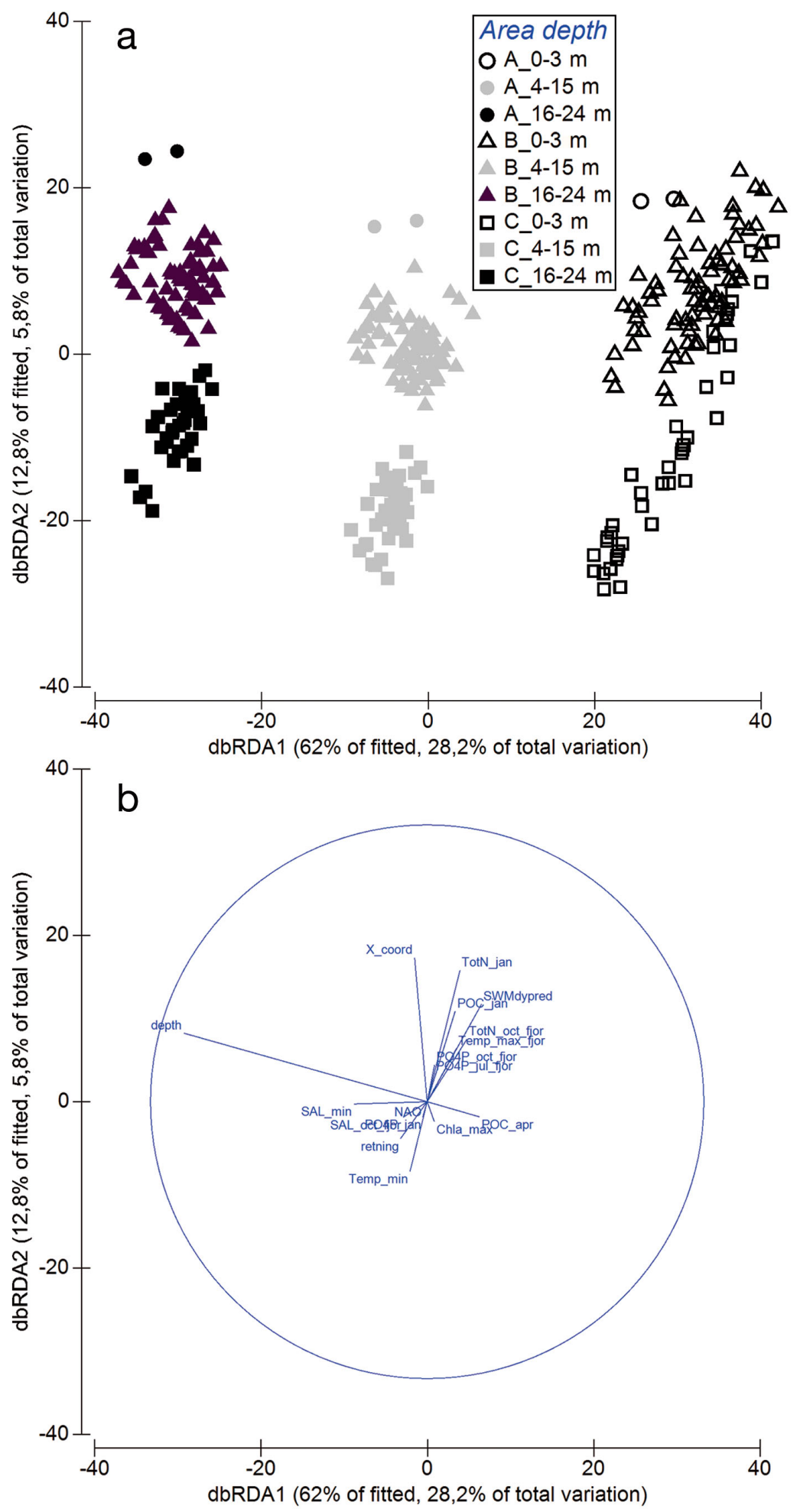

Fig. 6. (a) dbRDA plot of Bray Curtis similarity between samples based on hard bottom communities at stations in Outer Oslofjord (A), southeast coast (B) and southwest coast (C) and from different depth zones (0-3, 4-15, and 16-24 m) through the period 1991 to 2010. (b) Overlay vectors of the different variables and how they account for variation in panel (a) according to longitude, NAO (December to February), wave exposure level (SWM), nutrient and particle concentrations from different periods, minimum temperature $\left(T_{\min }\right)$ and maximum temperature the previous summer $\left(T_{\max }\right)$ 
see Supplement 3 at www.int-res.com/ articles/suppl/m530p029_supp.pdf). In the intermediate depth zone, more perennial red algae dominated along with kelp (Laminaria hyperborea and Saccharina latissima), and various sessile macroinvertebrates. In the deep zone (16 to $24 \mathrm{~m})$, there were generally more macroinvertebrates and fewer algae. In total, 58 species explained $90 \%$ of the similarity in the shallow depth zone, 68 species in the intermediate depth zone, and 53 in the deep zone.

The variance in species composition along the $y$-axis is mainly explained by longitude, wave exposure level (SWM), and nutrient and particle concentrations, with increasing wave exposure level, nutrient and particle concentrations, and temperature diagonally upwards in the plot. Samples taken from the outer Oslofjord and southeast coast (low in the plot) are separated from samples taken from the southeast coast (high in the plot).

Sixteen of 18 variables were selected in the best model to explain variation in community compositions through the monitoring period according to the $\mathrm{AICC}$ criterion in the DistLm analysis (Table 3). They explained $45.5 \%$ of the total variation in the dataset. The most important variables were depth, longitude, and wave exposure level. Winter NAO was also among the most important variables. Nutrient levels and amounts of particles prior to the monitoring (phosphate and total nitrogen in January, maximum chl a concentrations during spring bloom, and POC concentrations during January and April) had consistent and significant impacts on the hard bottom community structure. Nutrient and particle concentrations, the maximum summer temperature the previous year, and the salinity during October affected the community structure with a smaller, but significant, effect. Nutrient levels during spring (represented by phosphate concentrations from April) and POC from July the previous year were excluded from the model.

Occurrences of the dominating kelp Laminaria hyperborea and most sessile macroinvertebrates increased after cold and dry winters (negative NAO, low $T_{\min }$ see Supplement 4 at www.int-res.com/ articles/suppl/m530p029_supp.pdf). L. hyperborea decreased after particularly warm summers (high $T_{\max }$ ), while the occurrences of filamentous algae generally increased. Occurrences of both macroalgae and macroinvertebrates generally decreased in years with low minimum salinity $\left(\mathrm{S}_{\min }\right.$ occurred during melting periods in the spring), while the responses to salinity in the previous October were more variable. Filamentous algae generally increased in occurrences after periods when nutrient concentrations were high (phosphate in January and the previous July and October and total nitrogen in January and the previous October), while kelp and many (but not all) perennial algae decreased. An exception was the perennial brown alga Halidrys siliquosa, responding positively to extreme temperatures and low salinity. Occurrences of most species, including red algae (e.g. Delesseria sanguilenta abundant in the deep sublittoral), decreased after periods with high particle concentrations (POC in January and April). More species decreased as a response to high particle concentrations in January, when the phytoplankton production is negligible, compared to April. Responses were variable to the maximum phytoplankton biomass (maximum chl a). Algae generally dominated the most important species responsible for the observed community variation. Macroinvertebrates generally responded to climate (NAO and $\mathrm{T}_{\min }$ ), salinity (in October), and particles (maximum biomass of 
phytoplankton, chl a maximum) but not to nutrients. Exceptions were Mytilus edulis and Asterias rubens responding similarly to a number of variables. Noticeably also, Electra pilosa, Laomedea geniculata, and Membranipora membranacea responded similarly to kelp L. hyperborea.

\section{DISCUSSION}

Our study is among the first from temperate waters to address how rocky bottom ecosystems respond to combined effects of climate change and eutrophication. We have shown how hard bottom communities on the outer Skagerrak coast responded to environmental variables including variables related to climate and eutrophication in the period 1990 to 2010. The benthic ecosystems were overall dominated by numerous perennial and annual algae and rich communities of sessile macroinvertebrates. The ecological status was overall good, and the communities were generally diverse and species-rich. The environment in the monitored area is subjected to varying conditions, for example, in relation to waves and ice (Syvertsen et al. 2009), and $54 \%$ of the total variance could not be explained by the available variables. Physical factors including factors varying with depth, wave exposure level, and biogeographical region (longitude) explained a large part of the variance for which the analysis could account (36\% according to the DistLm analysis; Table 3). The total diversity did not change much across the Norwegian Skagerrak coast according to the mixed GAM analyses, but the DistLm showed structural changes in the communities reflecting biogeographical regions (Brattegard \& Holthe 1997). Wave exposure is generally high on these outer coasts and was one of the main factors driving the community composition. This factor is linked to water movement determining exchange of nutrients and gases and acting as a disturbance (Wheeler 1980, Norderhaug et al. 2012). The vertical species composition was most probably related to tides and desiccation in the surface, depthdependent factors like light conditions, and differences in fluctuation of the conditions: at 0 to $3 \mathrm{~m}$ depth, the light conditions are good, wave forces are strong, and physical conditions are fluctuating (salinity and temperature) and in periods extreme. This depth zone was dominated by littoral species, opportunistic annual red, green, and brown algae (Supplement 3 ) that grow quickly in favourable conditions. At intermediate depths (4 to $15 \mathrm{~m}$ ) with less fluctuating conditions, kelp formed dense forests, and the highest species richness and diversity were found. Perennial and annual macroalgae and -invertebrates characterising the rich community usually found in kelp forests were abundant (Christie et al. 2009). The community composition shift between 3 and $4 \mathrm{~m}$ was related to the upper kelp forest border. The shift in the community composition between 14 and $15 \mathrm{~m}$ was linked to the lower depth for kelp forests. At greater depths $(>16 \mathrm{~m})$, where light conditions are poor and the physical conditions are more stable than in shallow water, red algae and macroinvertebrate communities dominated.

Variables related to global warming and eutrophication had small (10\% in total; Table 3 ) impacts on the hard bottom communities. However, the impact patterns were consistent spatially and temporally and across uni- and multivariate analysis and indicated periods with signs of ecosystem stress related to warming and eutrophication. In addition to the main physical factors, extreme temperatures had the most important impact on benthic species richness and diversity. In particular, summers with maximum temperatures above $18^{\circ} \mathrm{C}$ had negative effects on species richness and diversity in June the following year (Table 2, Supplement 1). Also, particularly cold years with low minimum temperature during winter had a negative effect on species richness and diversity. During some winters, temperatures below $0^{\circ} \mathrm{C}$ were recorded at $>20 \mathrm{~m}$ depth lasting for $>1 \mathrm{wk}$, and this may have been below tolerance limits for many species. Since the temperature variation was largest in shallow water, it was not surprising that shallow water species were most affected by extreme temperatures (Supplements $3 \& 4$ ). While maximum temperatures were the most important climate-related variables affecting species richness and diversity, winter NAO had the largest influence on the community structure among the climate variables used and was associated with the highest diversity during mild winters (Table 3, Supplement 1). The general climate affected more species in deeper water than extreme temperatures (Supplement 4). We cannot conclude on the underlying effect of NAO on the community structure, but since diversity generally was reduced by reduced salinity and increased concentration of particles (Table 2, Supplement 3), high diversity in years with positive winter NAO was probably mainly an effect of temperature and mild winters. Years in which temperatures were high early in the year probably implied that benthic communities were more developed at the time of monitoring (June) than in cold and dry years as a result of seasonal succession. 
The presence of sessile organisms reflects environmental variation over time (Gray et al. 1990). Small disturbances (e.g. inputs of nutrients) may increase benthic diversity by increasing available nutrient resources (the so-called enrichment phase), while large disturbances (e.g. large nutrient inputs) may reduce biodiversity by increasing stress and excluding vulnerable species (Jackson 1977, Gray 1992). The response plots in Supplement 1 showed variable responses to nutrients in different seasons (e.g. species richness and diversity were increasing with increasing phosphate concentrations in July but decreasing with phosphate concentrations in October). This pattern probably reflected interspecific differences in e.g. uptake and growth season between algae. Community changes result from the responses from individual species and vary according to life history and ecological traits. Several annual filamentous algae increased with increasing nutrients in July (Supplement 4). Slow-growing perennial brown algae, including kelp, take up nutrients during autumn and winter when the abundances of filamentous algae are reduced (Hatcher et al. 1977, Moy \& Christie 2012). In periods with high nutrient concentrations during summer, they may be overgrown by fast-growing filamentous algae (Andersen et al. 2011). Consequently, kelps responded negatively to high nutrient concentrations in July but positively in October. This pattern had indirect effects on the community associated with kelp (Christie et al. 2009). A number of epiphytic species associated with kelp laminas (e.g. Electra pilosa, Laomedea geniculata, and Membranipora membranacea) responded in the same way as kelp to all variables and showed the importance of kelp as a habitat-forming species. However, interpretations based on nutrient concentration measurements from the water during the growing season of phytoplankton should be made with some caution. From spring to autumn, a large portion of the available nutrients is bound in the plankton, and the measured concentrations in the water may not reflect the amount available in the system. Most reliable nutrient measurements for describing the nutrient conditions are performed during winter when the phytoplankton production is negligible. In January (see total nitrogen in January in Supplement 1), species richness and diversity had a concave response, with lowest benthic diversity in years with the highest nitrogen concentrations, while highest diversity was found in years with intermediate concentrations. Thus, according to general eutrophication models (sensu Pearson \& Rosenberg 1978), our benthic communities may have been in an elevated eutrophication state beyond the enrichment phase during periods with high nutrient levels (see e.g. Gray 1992). During years with low nutrient concentrations, the communities seemed to be in the enrichment phase and diversity increased with increasing nutrient concentrations.

High particle concentrations early in the year (particulate organic carbon in January and April) had a small but consistently negative effect on species richness and diversity (Tables $2 \& 3$, Supplements $1 \& 4$ ). The effect of maximum phytoplankton biomass (chl a) was much more variable (Supplements 1 \& 4). POC contains all types of organic carbon, including particles of terrestrial origin (particularly during melting season in spring), and we think this pattern indicates that particles of marine origin (phytoplankton) have less negative effects than terrestrial particles. Particles of different content affect the communities in various ways. In the water column, they cause darkening effects (Aksnes et al. 2009). On the sea floor, encrusting species and settling reproductive propagules are vulnerable to particles (e.g. Jackson 1977, Moy \& Christie 2012). To filtrating organisms, POC is food, and they may benefit from high concentrations of particles with high nutrient content, while low nutrient content dilutes the food value and is expected to increase the physiological costs from utilizing the particles as food.

The large unexplained part of the variance $(54 \%$; Table 3) could probably be attributed to both stochastic environmental variation and also the discrepancy in the sampling design in time and space (i.e. water samples and biological samples were taken close to each other but not at the same location). This inherent limitation of the monitoring design was necessary for cost reasons but increased the variance in the dataset. Although it has been indicated that the hydrochemical stations represent the water at the biological stations well (NIVA 2002), we would have expected the explanatory variables from water samples to explain more of the explained variance if they were taken at the same time and place as the biological data. In other words, we think the analyses underestimate the importance of climate and eutrophication compared to the physical factors, biogeographical region, and unknown factors (unexplained variance). A number of other causes are likely to contribute to the unexplained part of the variance: the monitoring program was started after the Prymnesium polylepis bloom in 1988, which had severe effects on benthic communities (Gjøsæeter et al. 2000). The ecosystems seemed to be in a recovery phase during the beginning of our time-series, and our chl a 
data series beginning in 1990 could not be analyzed to take this into account. Furthermore, all species were treated as equals in our study without taking into account their ecological function (Loreau 2000). While many species, including species living as epiphytes on kelp laminas in Supplement 4, may be referred to as 'ecological passengers' (Walker 1992) without important function, some species with a particularly important ecosystem function such as habitat-building species, including macrophytes (Christie et al. 2003, 2009), structuring predators (Moksnes et al. 2008), and grazers (Norderhaug \& Christie 2009), may be referred to as 'ecological engineering species' (Jones et al. 1994) or 'keystone species' (Duffy \& Hay 2001). Several other sources of unexplained variance include recruitment success, benthicpelagic couplings, and biological interactions (Begon et al. 1990). The strong and equal response of the shallow water filterfeeder Mytilus edulis and its predator Asterias rubens to a number of variables, including nutrients, was noticeable. While macroinvertebrates are not expected to respond to nutrient concentrations, there must have been strong interactions between the environment (e.g. space or food supply), $M$. edulis, and A. rubens. Some species seemed to show opportunistic behavior and increased when other were reduced, perhaps because of available space. Halidrys siliquosa was one such species, and it is tolerant to variable temperature and salinity (see www.marlin.ac.uk) and may be confined to rock pools (Steele et al. 2001). Corallina officinalis respond to reduced cover of erect algae (Pedersen \& Snoeijs 2001). Also, delayed responses are expected in shallow sublittoral benthic systems, which may integrate eutrophication over time without responding before phase shifts to a higher trophic state occur suddenly (Kraufvelin et al. 2006, Moy \& Christie 2012).

This and other studies from the Skagerrak and greater North Sea indicate a pattern of increasing effects from eutrophication and climate variation toward the coast. On the inner coast, a large-scale regime shift and loss of sugar kelp Saccharina latissima has been observed (Moy \& Christie 2012). Our study from the outer coast detected rich communities mainly structured by physical (and unexplained) variance. We also detected small but significant negative impacts from eutrophication and reduced diversity in periods with a climate as expected in the future. Available soft bottom studies from the central North Sea covering $>20$ yr suggest small changes in the benthos. According to Kröncke et al. (2011), large-scale spatial distribution of macrofaunal off- shore communities in the North Sea hardly changed between 1986 and 2000. According to Frid et al. (2009), there has been no trend in abundance or general richness within the monitored period. They found a trend in composition of benthos driven by impact from fishing, global warming, and altered fluxes of phytoplankton but found no change in dominant taxa and richness. Shallow water communities are more influenced by local and terrestrial inputs than deeper soft bottom communities, and communities on the inner coast are more influenced by land run-off than communities on the outer coast (Kemp et al. 2005). The underlying mechanism(s) responsible for the regime shifts on the inner Skagerrak coast with replacement of sugar kelp Saccharina forests by filamentous algae is not well understood but was most likely linked to warm summer temperatures in combination with eutrophication (Moy \& Christie 2012). Andersen et al. (2011) showed that epiphyte fouling most likely has prevented sugar kelp from recovering. Consequently, actions to reduce eutrophication in coastal areas and mitigation actions against effects from climate change should have high priority, including actions to reduce runoff from land.

Environmental management is aiming at a moving target, and while the authorities have put emphasis on reducing discharges of nutrients to the Skagerrak (Syvertsen et al. 2009), eutrophication is increasing (Moy \& Christie 2012, Frigstad et al. 2013). There seems to have been a shift towards the increasing importance of local discharge sources relative to regional sources. Inputs of nutrients by ocean currents from the south North Sea to Norwegian waters have decreased since the mid-1990s (Aure \& Magnusson 2008), but local inputs from some rivers have increased (Skarbøvik et al. 2010). This has resulted in a shift to increased seston concentrations in coastal waters compared to before 2000 (Frigstad et al. 2013). A warmer climate with more precipitation will increase summer temperatures further, the frequency of floods (e.g. like the flood in River Glomma in 2013), and melting periods with run-off early in the year when important habitat-forming species recruit (Moy \& Christie 2012). This may call for more drastic actions from the environmental authorities if increased eutrophication effects are to be avoided in the future.

Long time-series, covering environmental parameters and biology, are essential in order to detect manmade changes early (early warning signals), to identify important pressures, and to increase the understanding of cause-effect relationships in coastal ecosystems. Ecological communities may not res- 
pond linearly to stressors but may absorb disturbances until they suddenly shift to alternative states with different structure, function and production (Scheffer et al. 2001). Multiple human stressors reduce the resilience of marine ecosystems and thus increase the vulnerability to state shifts (Möllmann et al. 2015). Climate- and eutrophication-related events including the Prymnesium polylepis bloom in 1988 (Olsgard 1993) and the large-scale loss of S. latissima on the inner Skagerrak coast around 2000 (Moy \& Christie 2012) had severe effects on benthic ecosystems. These large-scale events highlight the importance of environmental monitoring. It is far more difficult to understand underlying mechanisms behind manmade changes in nature if no data exist prior to the changes. Time-series data have been recognized as a basis to analyse and better understand eutrophication and climatic change (Frost et al. 2006), which is fundamental for ecosystem-based management (EBM $i$ Curtin \& Prellezo 2010) capable of implementing effective actions and to manage coastal ecosystems and commercial activities efficiently and sustainably (Syvertsen et al. 2009). The monitoring data from the Coastal Monitoring Program (KYO) has proven valuable for understanding early ecosystem responses from climate change and eutrophication and, perhaps most importantly, how they interact.

Acknowledgements. Data for this study were sampled through The Coastal Monitoring Programme (KYO) which was developed by NIVA and financed by the Norwegian Environment Agency (former Norwegian Pollution Control Authority). We thank the Agency and NIVA for funding. We also thank the Ministry of Climate and Environment for funding monitoring of 'core stations' in KYO through a programme for sustaining valuable time-series from 2013.

\section{LITERATURE CITED}

Aksnes DL, Ohman MD (2009) Multi-decadal shoaling of the euphotic zone in the southern sector of the California Current System. Limnol Oceanogr 54:1272-1281

Aksnes DL, Dupont N, Staby A, Fiksen Ø, Kaartvedt S, Aure J (2009) Coastal water darkening and implications for mesopelagic regime shifts in Norwegian fjords. Mar Ecol Prog Ser 387:39-49

Andersen GS, Steen H, Christie H, Fredriksen S, Moy FE (2011) Seasonal patterns of sporophyte growth, fertility, fouling, and mortality of Saccharina latissima in Skagerrak, Norway: implications for forest recovery. J Mar Biol 2011:690375, doi:10.1155/2011/690375

Anderson MJ (2001) A new method for non-parametric multivariate analysis of variance. Austral Ecol 26:32-46

Aure J, Magnusson J (2008) Mindre tillførsel av næringssalter til Skagerrak (Decreased supply of nutrients to the
Skagerrak coast). In: Kyst og Havbruk 2. Institute of Marine Reserarch, Bergen

Barton K (2013) MuMIn: Multi-model inference. R package version 1.9.5, available at http://CRAN.R-project.org/ package $=$ MuMIn

Begon M, Harper JL, Townsend CR (1990) Ecology. Individuals, populations and communities. Blackwell Scientific Publications, Oxford

Bjerknes J (1964) Atlantic air-sea interaction. Adv Geophys 10:1-82

Boesch DF, Hecky R, O'Melia C, Schindler D, Seitzinger S (2006) Eutrophication of Swedish Seas. Report 5509 to Swedish Environmental Protection Agency. Naturvårdsverket Stockholm

Brattegard T, Holthe T (1997) Distribution of marine, benthic macroorganisms in Norway. A tabulated catalogue. Research Report for Directorate for Nature Management. Directorate for Nature Managament, Trondheim

Burnham KP, Anderson DR (2002) Model selection and multimodel inference: a practical information-theoretic approach, 2nd edn. Springer, New York, NY

Burnham KP, Anderson DR, Huyvaert KP (2011) AIC model selection and multimodel inference in behavioral ecology: some background, observations, and comparisons. Behav Ecol Sociobiol 65:23-35

Christie H, Jørgensen NM, Norderhaug KM, WaageNielsen E (2003) Species distribution and habitat exploitation of fauna associated with kelp (Laminaria hyperborea) along the Norwegian coast. J Mar Biol Assoc UK 83:687-699

Christie H, Norderhaug KM, Fredriksen S (2009) Macrophytes as habitat for fauna. Mar Ecol Prog Ser 396:221-233

Clarke KR, Warwick RM (2001) Change in marine communities. An approach to statistical analysis and interpretation. Plymouth Marine Laboratory, Plymouth

> Connell JH (1961) Effects of competition, predation by Thais lapillus, and other factors on natural populations of the barnacle Balanus balanoides. Ecol Monogr 31:61-104

> Curtin R, Prellezo R (2010) Understanding marine ecosystem based management: a literature review. Mar Policy 34: 821-830

$>$ Dahl E, Johannessen T (1998) Temporal and spatial variability of phytoplankton and chlorophyll a: lessons from the south coast of Norway and the Skagerrak. ICES J Mar Sci 55:680-687

> Diaz RJ, Rosenberg R (2008) Spreading dead zones and consequences for marine ecosystems. Science 321:926-929

Duffy JE, Hay M (2001) The ecology and evolution of marine consumer-prey interactions. In: Bertness MD, Gaines SD, Hay ME (eds) Marine community ecology. Sinauer Associates, Sunderland, MA, p 131-157

$>$ Edvardsen B, Eikrem W, Throndsen J, Sáez AG, Probert I, Medlin LK (2011) Ribosomal DNA phylogenies and a morphological revision provide the basis for a revised taxonomy of the Prymnesiales (Haptophyta). Eur J Phycol 46:202-228

> Frid CIJ, Paramour OAL, Scott CI (2005) Ecosystem-based fisheries management: progress in the NE Atlantic. Mar Policy 29:461-469

Frid CLJ, Garwood PR, Robinson L (2009) The North Sea benthic system: a 36 year time-series. J Mar Biol Assoc UK 89:1-10

Frigstad H, Andersen T, Hessen DO, Jeansson E and others (2013) Long-term trends in carbon, nutrients and stoi- 
chiometry in Norwegian coastal waters: evidence of a regime shift. Prog Oceanogr 111:113-124

Frost MT, Jefferson R, Hawkins SJ (2006) The evaluation of time series: their scientific value and contribution to policy needs. Report 11 for the Department for Environment, Food and Rural Affairs (DEFRA). Marine Biological Association, Plymouth

> Gjøsæter J, Lekve K, Stenseth NC, Leinaas HP and others (2000) A long-term perspective on the Chrysochromulina bloom on the Norwegian Skagerrak coast 1988: a catastrophe or an innocent incident? Mar Ecol Prog Ser 207:201-218

Gray JS (1992) Eutrophication in the sea. In: Columbo G, Ferrari I, Ceccherelli VU, Rossi R (eds) Marine eutrophication and population dynamics. Olsen \& Olsen, Fredensborg, p 3-15

Gray JS, Clarke KR, Warwick RM, Hobbs G (1990) Detection of initial effects of pollution on marine benthos: an example from the Ekofisk and Eldfisk oilfields, North Sea. Mar Ecol Prog Ser 66:285-299

Harley CDG, Hughes AR, Hultgren KM, Miner BG and others (2006) The impacts of climate change in coastal marine systems. Ecol Lett 9:228-241

Hatcher BG, Chapman ARO, Mann KH (1977) An annual carbon budget for the kelp Laminaria longicruris. Mar Biol 44:85-96

Hill MO (1973) Diversity and evenness: a unifying notation and its consequences. Ecology 54:427-432

Isæus M (2004) Factors structuring Fucus communities at open and complex coastlines in the Baltic Sea. Filosofie doktorexamen, Stockholm University

> Jackson JBC (1977) Competition on marine hard substrata: the adaptive significance of solitary and colonial strategies. Am Nat 111:743-767

Jones CG, Lawton JH, Shachak M (1994) Organisms as ecosystem engineers. Oikos 69:373-386

Kålås JA, Viken À, Bakken T (2006) Norwegian red list. Norwegian Species Information Centre, Trondheim

Kemp WM, Boynton WR, Adolf JE, Boesch DF and others (2005) Eutrophication of Chesapeake Bay: historical trends and ecological interactions. Mar Ecol Prog Ser 303:1-29

Kraufvelin P, Moy FE, Christie H, Bokn TL (2006) Nutrient addition to experimental rocky shore communities revisited: delayed responses, rapid recovery. Ecosystems 9:1076-1093

Kröncke I, Reiss H, Eggleton JD, Bergman MJN and others (2011) Changes in North Sea macrofauna communities and species distribution between 1986 and 2000. Estuar Coast Shelf Sci 94:1-15

Lindley JA, Batten SD (2002) Long-term variability in the diversity of North Sea zooplankton. J Mar Biol Assoc UK 82:34-40

Loreau M (2000) Biodiversity and ecosystem functioning: recent theoretical advances. Oikos 91:3-17

Mankovsky VI, Solovev MV, Vladimirov MV (1996) Variability of the Black Sea hydrooptical parameters in 1922-1992. Океанология (Oceanology) 36:370-376 (in Russian with English Abstract)

> Manton I, Parke M (1962) Preliminary observations on scales and their mode of origin in Chrysochromulina polylepis sp. nov. J Mar Biol Assoc UK 42:565-578

Moksnes PO, Gullström M, Tryman K, Baden S (2008) Trophic cascades in a temperate seagrass community. Oikos 117:763-777
Möllmann C, Folke C, Edwards M, Conversi A (2015) Marine regime shifts around the globe: theory, drivers and impacts. Philos Trans R Soc Lond B Biol Sci 370: 20130260

- Moy F, Christie H (2012) Large-scale shift from sugar kelp (Saccharina latissima) to ephemeral algae along the south and west coast of Norway. Mar Biol Res 8:309-321

Nilsson HC, Rosenberg R (2000) Succession in marine benthic habitats and fauna in response to oxygen deficiency: analysed by sediment profile imaging and by grab samples. Mar Ecol Prog Ser 197:139-149

NIVA (Norwegian Institute for Water Research) (2002) Statlig program for overvåking: Kystovervåkingsprogrammet. Langtidsovervåking av miljøkvaliteten i kystområdene av Norge. 10-årsrapport 1990-1999. NIVA Report 4543. NIVA, Oslo

Norderhaug KM, Christie H (2009) Sea urchin grazing and kelp re-vegetation in the NE Atlantic. Mar Biol Res 5:515-528

Norderhaug KM, Ledang AB, Trannum HC, Bjerkeng B and others (2011a) Long-term monitoring of environmental quality in the coastal regions of Norway. Report for 2010. Klif report TA-2777. Klif (Klima og forurensningsdirektoratet), Oslo

Norderhaug KM, Trannum H, Ledang AB, Bjerkeng B and others (2011b) The Coastal Monitoring Programme yearly report. Data report. Klif report TA-2815. Klif (Klima og forurensningsdirektoratet), Oslo

Norderhaug KM, Christie H, Andersen GS, Bekkby T (2012) Does the diversity of kelp forest fauna increase with wave exposure? J Sea Res 69:36-42

Olsgard F (1993) Do toxic algal blooms affect subtidal softbottom communities? Mar Ecol Prog Ser 102:269-286

OSPAR (1998) OSPAR strategy to combat eutrophication, 1998-18. OSPAR Commission, London

OSPAR (2009) Monitoring and assessment series 447. OSPAR Commission, London

OSPAR (2010) Quality status report 2010. OSPAR Commission, London

Pearson TH, Rosenberg R (1978) Macrobenthic succession in relation to organic enrichment and pollution of the marine environment. Ocean Mar Biol Ann Rev 16:229-311

Pedersen A, Rygg B (1990) Program for langtidsovervåkning av trofiutvikling i kystvannet langs Sør-Norge. Part I. Bentiske organismesamfunn. NIVA Note O-89131, NIVA, Oslo

Pedersen M, Snoeijs P (2001) Patterns of macroalgal diversity, community composition and long-term changes along the Swedish west coast. Hydrobiologia 459:83-102

R Development Core Team (2012) R: a language and environment for statistical computing. R Foundation for Statistical Computing, Vienna, available at www.r-project.org

> Rabalais NN, Turner RE, Díaz RJ, Justi D (2009) Global change and eutrophication of coastal waters. ICES J Mar Sci 66:1528-1537

Sanden P, Håkansson B (1996) Long-term trends in Secchi depth in the Baltic Sea. Limnol Oceanogr 41:346-351

Scheffer M, Carpenter S, Foley JA, Folke C, Walker B (2001) Catastrophic shifts in ecosystems. Nature 413:591-596

Shannon CE, Weaver W (1963) The mathematical theory of communication. University of Illinois Press, Urbana, IL

Skarbøvik E, Stålnacke P, Kaste Ø, Selvik J and others (2010) Riverine inputs and direct discharges to Norwegian coastal waters - 2009. Klif report TA-2726. Klif (Klima og forurensningsdirektoratet), Oslo 
Steele JH, Thorpe SA, Turekian KK (2001) Marine biology. Encyclopedia of ocean sciences, 2nd edn. Elsevier, London

Steneck RS, Vavrinec J, Leland AV (2004) Accelerating trophic level dysfunction in kelp forest ecosystems of the western North Atlantic. Ecosystems 7:323-332

Syvertsen EE, Gabestad H, Bysveen I, Salmer M and others (2009) Vurdering av tiltak mot bortfall av sukkertare. Klif report 2585. Klif (Klima og forurensningsdirektoratet), Oslo

ter Braak CJF, Smilauer P (2002) CANOCO reference manual and CanoDraw for Windows user's guide: software for canonical community ordination (version 4.5). Microcomputer Power, Ithaca, NY

Editorial responsibility: Just Cebrian, Dauphin Island, Alabama, USA
Thomas CD, Cameron A, Green RE, Bakkenes M and others (2004) Extinction risk from climate change. Nature 427: 145-148

Walker B (1992) Biological diversity and ecological redundancy. Conserv Biol 6:18-23

Wheeler WN (1980) Effect of boundary layer transport on the fixation of carbon by the giant kelp Macrocystis pyrifera. Mar Biol 56:103-110

Wood SN (2011) Fast stable restricted maximum likelihood and marginal likelihood estimation of semiparametric generalized linear models. J R Stat Soc B 73:3-36

Zuur AF, Latuhihin MJ, Ieno EN, Baretta-Bekker JG, Smith GM, Walker NJ (2009) Mixed effects models and extensions in ecology with R. Springer, Newburgh, p 423-446

Submitted: December 23, 2013; Accepted: April 8, 2015

Proofs received from author(s): June 9, 2015 